\title{
Responses of intermittent pond ciliate populations and communities to in situ bottom-up and top-down manipulations
}

\author{
Oksana P. Andrushchyshyn, A. Katarina Magnusson, D. Dudley Williams* \\ Surface and Groundwater Ecology Research Group, Department of Life Sciences, University of Toronto at Scarborough, \\ 1265 Military Trail, Ontario M1C 1A4, Canada
}

\begin{abstract}
Pond physicochemical characteristics and bottom-up effects were more important than top-down effects in governing ciliate community structure in 2 adjacent intermittent ponds in Southern Ontario, Canada. The ciliates showed a bimodal seasonal pattern with abundances peaking early and late in the hydroperiods, and the communities showed a strong seasonal succession of species only $15 \%$ of the 162 ciliate species were present throughout the hydroperiods. Less than half of the species occurred in both ponds. Adding riparian leaf litter to large pond enclosures affected several physicochemical variables, increased bacterial abundance, and promoted the appearance of particular species - many of which are known to be associated with nutrient- or organic matter-enriched conditions. This treatment resulted in higher ciliate abundance (mainly small-sized bacterivores) and lower ciliate diversity in mid-hydroperiod in one of the ponds. The removal of plant litter generally produced effects in the physicochemical variables that were opposite to those seen in the leaf litter addition, and resulted in a $15 \%$ decrease in the proportion of ciliate bacterivores in one pond. The effects of top-down manipulations (i.e. prevention of aerial colonization of insects) were minor. Many treatment effects were season-, and pond-specific. The measured environmental variables (including pond and treatments) explained half of the variation in ciliate abundance, one-third of the species diversity, and one-fifth of the species composition. Pond characteristics and the leaf litter additions were the most important factors for determining ciliate abundance (together with chlorophyll a), diversity (together with dissolved oxygen), and community composition (together with season).
\end{abstract}

KEY WORDS: Ciliates - Seasonal succession - Temporary ponds - Resource addition - Resource removal $\cdot$ Predator exclusion $\cdot$ Seasonal succession $\cdot$ Top-down $\cdot$ Bottom-up

\section{INTRODUCTION}

Free-living ciliates are unicellular, eukaryotic, mainly phagotrophic protists that play important metabolic roles in freshwater ecosystems (Fenchel 1987, review by Beaver \& Crisman 1989, Finlay \& Fenchel 2004). Ciliates and other protists are the most important grazers of microbes in aquatic environments, the only grazers of any importance in anoxic habitats, and usually predominate in sediments. Although ciliate biomass typically accounts for slightly less than $10 \%$ of total benthic invertebrate biomass, ciliate production may equal or even exceed invertebrate production (Finlay \& Esteban 1998a). Compared with meio- and macrofauna, ciliates consume more food, have a higher respiration rate per mass unit, have shorter generation times, and reproduce much faster, all of which contribute to their dominance in the turnover of pond organic matter.

Although there is extensive work on ciliate communities and populations in different freshwater habitats including ponds (Wang 1928, Goulder 1971, Hatano \& Watanabe 1981, Kusano et al. 1987, Madoni 1991, Müller et al. 1991, Guhl et al. 1994, Finlay \& Esteban 1998b, Madoni \& Sartore 2003), lakes (Goulder 1974, review by Beaver \& Crisman 1989, Müller et al. 1991, James et al. 1995), reservoirs (Salvado \& Gracia 1991, Šimek et al. 1995), and other water bodies (Bick 1973), almost no data exist 
on ciliate communities of intermittent ponds (Andrushchyshyn et al. 2003, but see Picken 1937).

Intermittent ponds are bodies of water that experience a recurrent dry phase of varying length that is predictable in its onset and duration (Williams 1997). The most important influences on their biota are length of the aquatic phase (hydroperiod), pattern of disappearance of the water, degree of intraspecific competition and predation, and the seasonal influx of aerial colonizers (Williams 2006). Thus, the particular environment in intermittent ponds makes these habitats ideal arenas for testing hypotheses about communityregulating mechanisms. The relative roles of bottomup (i.e. resource availability) and top-down (i.e. predation) mechanisms versus physicochemical constraints for governing intermittent pond communities are not known. Ciliates are ideal organisms for such studies because they have short generation times and respond rapidly to environmental change. Previous research on protists in permanent waters suggests that top-down control from zooplankton is stronger than bottom-up effects from nutrient addition (review in Sanders \& Wickham 1993), and that bottom-up effects may be important primarily in oligotrophic waters, whereas top-down effects are more important in eutrophic waters (Berninger et al. 1993).

The aim of this study was to explore key factors influencing ciliate communities in 2 intermittent ponds. To do this, we determined, in situ: (1) the natural, temporal variation in ciliate abundance, diversity, and community structure in 2 adjacent ponds, and related these to environmental factors; and tested (2) the role of bottom-up effects by indirect manipulation of resource availability (leaf-litter addition vs leaf-litter removal; bacteria and phytoplankton are the main prey for ciliates) in large enclosures, and (3) the role of top-down effects by excluding predatory aerial colonizers from other enclosures. We hypothesize that an increase of leaf litter material will lead to increasing resources for the ciliates, which will be reflected in the ciliate species abundance, diversity, and community composition. We expect the removal of leaf litter to have the opposite effect to the resource addition. We further expect that the removal of aerial colonizers will propagate down through the food web, via zooplankton, and influence the ciliate communities.

\section{MATERIALS AND METHODS}

Sampling sites. The ciliate populations were sampled weekly throughout the hydroperiod in 2002 in 2 fishless, intermittent ponds located in Vandorf, Ontario $\left(44^{\circ} 00^{\prime} \mathrm{N}, 79^{\circ} 23^{\prime} \mathrm{W}\right)$. Pond I was approximately 0.25 ha in area with a maximum depth of $39 \mathrm{~cm}$, and held water from 15 March until 4 July (112 d). Pond II was smaller ( 0.1 ha) but deeper (maximum $48 \mathrm{~cm}$ ), and held water from 18 March until 17 June (92 d). Mixed deciduous trees surrounded both ponds, although Pond II was more open in exposure. The vegetation in Pond I was heterogeneous whereas in Pond II it consisted mainly of the grass Phalaris sp.

The same experimental set-up was established in both ponds for 2 reasons: (1) to achieve proper replication, and (2) as a means to assess whether the same manipulations would yield similar results in ponds with different vegetation structure. The ciliate data presented here are a part of an ongoing, major study of top-down and bottom-up responses on intermittent pond community structure.

Experimental design. The experimental design included 2 replicates per pond of each of 3 manipulations (1 top-down and 2 different bottom-up manipulations), and 2 controls in which no manipulations were performed (namely, an enclosure control, and a natural 'pondwater' control). All manipulations were performed in enclosures made of circular galvanized-steel sheets (each enclosing an area of pond bed measuring $4.2 \mathrm{~m}^{2}$ ) that were placed in homogeneous areas of each pond. The enclosures were assembled so as to prevent any exchange of water and organisms between the inside and outside (pond) water, and were set $5 \mathrm{~cm}$ into the pond beds. The enclosure controls ('c') consisted of enclosed areas, in which no manipulations were performed, which served as reference areas to the top-down and bottom-up manipulations. The pondwater controls ('o') comprised 2 non-enclosed areas of the pond that were used to assess any potential enclosure effects.

To study top-down effects on the ciliate community, invertebrate aerial colonization was prevented by a fine mesh-net $(1 \mathrm{~mm})$ that covered the openings of 2 enclosures in each pond. This treatment (referred to as top-down manipulation, 'p-') chiefly excluded adult beetles and odonates, but also reduced the number of chironomid and mosquito larvae. This treatment was designed primarily to examine the effects of predators on pond macroinvertebrates, but the manipulation was also useful in examining indirect top-down effects on the ciliate communities.

The resource manipulation consisted of 2 treatments: addition and removal of riparian leaf- and plant litter (' $\mathrm{r}+$ ' and ' $\mathrm{r}-$ ', respectively). In the latter, riparian leaf litter and decomposing plant material $(1.5 \pm 0.2 \mathrm{~kg}$ [ $\pm 1 \mathrm{SD}]$ in Pond I and $1.5 \pm 0.04 \mathrm{~kg}$ in Pond II) were removed the previous autumn (late-October). Double the amount of material that was removed from the resource removal enclosures was added (midNovember) to the resource addition enclosures in the form of dried $\left(100^{\circ} \mathrm{C}\right.$ for $\left.24 \mathrm{~h}\right)$ riparian leaf litter collected from the pond banks. 
The 2 ponds were subjected to identical experimental set-up; thus, each pond contained 8 enclosures (i.e. 2 replicates of each of the 3 manipulations and the enclosure control) and 2 non-enclosed areas (i.e. 2 replicates of the pondwater control).

Routine sampling. A weekly sampling programme comprised analyses for ciliates (Protista: Ciliophora), water chemistry (using a Hydrolab $\mathrm{H}_{2} \mathrm{O}$ multiprobe, Hydrolab; and portable Hach Kit spectrophotometer DR2000: Hach), bacteria (0.25 to $1 \mathrm{ml}$ pondwater stained with acridine orange, filtered, and counted under a epifluorescence microscope; Sorokin 1999), and chlorophyll a ( $\mathrm{chl}$ a) (0.25 l pondwater filtered and extracted in acetone: American Public Health Association 1995). Ciliate samples were taken by submerging an empty, closed $150 \mathrm{ml}$ container adjacent to the substrate; removing the lid and sealing it once full. Two such replicates were taken at each sampling site and these were pooled in the field. For enumeration, samples were preserved with mercury chloride $(2.5 \%$ final concentration, Sime-Ngando \& Groliere 1991) immediately after filling the containers. In the laboratory, after thorough mixing, $10 \mathrm{ml}$ were withdrawn from each sample, and placed in an Utermöhl chamber (Phyco Tech) for counting ciliates under an inverted microscope. Identification of ciliate species was done mostly on live samples (from a subsample extracted prior to preservation) on the same day they were collected. The internal organelles were visualized using KleinFoissner silver nitrate method for silverline system (Foissner et al. 1999). The following keys were used in the identifications: Kahl (1930, 1931, 1932, 1935), Bick (1972), Corliss (1979), Curds et al. (1982, 1983), Foissner et al. (1991, 1992, 1994, 1995, 1999), Foissner \& Berger (1996). Biomass (wet mass) for individual species was calculated using data presented in Foissner and Berger (1996) or using ciliate shape and size according to Chislenko (1968). At least 20 individuals for each species were measured to get a mean, which together with appropriate ciliate shape were used to compute volume $\left(1 \mathrm{\mu m}^{3}=1 \mathrm{pg}\right.$, i.e. specific gravity of the protoplasm is 1.0, Foissner \& Berger 1996).

Organisms, other than ciliates, present in the samples (e.g. algae, rotifers, flagellates, amoebae, gastrotrichs, and crustaceans) were recorded as: absent; present; or abundant, and were given the numerical values of 0,1 , and 4 respectively.

Statistical methods. Pond-, time-, and treatment effects on water chemistry, ciliate abundance, species richness (i.e. number of species), species diversity (Shannon's diversity index), and proportion of size-, and feeding groups, were analyzed using repeated measures ANOVA (ANOVAR) with 2 grouping factors: Pond (Pond

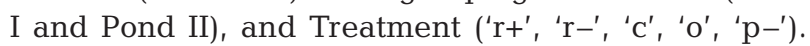
Abundance and biomass were log-transformed prior to analysis to better meet the underlying assumptions. Since the assumption of non-sphericity was violated (i.e. samples in the time series were not independent), we used the Greenhouse-Geiser (G-G) adjustment on all time interaction probabilities (Scheiner \& Gurevitch 2001). To minimize the risk of type I errors due to multiple independent tests, all statistically significant main and interaction effects were Bonferroni corrected. Planned post-hoc tests for interaction effects were conducted on days collapsed into early-, mid-, and late season, to increase the power of the analysis.

The influences of the various measured environmental variables on total ciliate abundance, diversity, and species richness were analyzed using stepwise (forward) regressions. The variables were log-transformed when necessary. The longitudinal scale did not cause any serious violation of the assumption of independence (>1.2 Durbin Watson, and $<0.7$ autocorrelation). The effects of the environmental variables, pond, season (i.e. days after flooding), and treatments on the ciliate species composition were evaluated with Canonical Correspondence Analysis (CCA). Prior to the CCA, the data were run in an unconstrained ordination, Detrended Correspondence Analysis (DCA), to find the overall variability in the ciliate data, and to test the gradient length (which was $>1.5$, i.e. long enough to use a unimodal distribution analysis). The first CCA was run without any covariables on 300 samples $\times 162$ species. A second CCA was run with days after flooding and ponds as covariables in order to evaluate the specific treatment effects. In biplots, the length of an arrow indicates the importance of an environmental variable, and the direction indicates what the axes represent. All ciliate abundances and environmental variables were log-transformed before the analyses (except days after flooding and water depth) and rare ciliate species were down-weighted. The scaling was focused on unit variance, and the scores optimized for inter-sample differences. The significance of each axis was estimated using the Monte Carlo test (199 permutations under the full model). The data were analyzed using STATISTICA (StatSoft) and CANOCO for Windows v.4.0 (Centre for Biometry).

\section{RESULTS}

\section{Physicochemical environment}

The water depth in Pond I was 20 to $35 \mathrm{~cm}$ for most of the hydroperiod before the pond rapidly dried out $112 \mathrm{~d}$ after flooding (Fig. 1). For the first $10 \mathrm{wk}$ in Pond II, the water depths were 25 to $50 \mathrm{~cm}$, before the pond slowly dried out $3 \mathrm{wk}$ later (92 d hydroperiod length). Water temperatures steadily increased as the season 

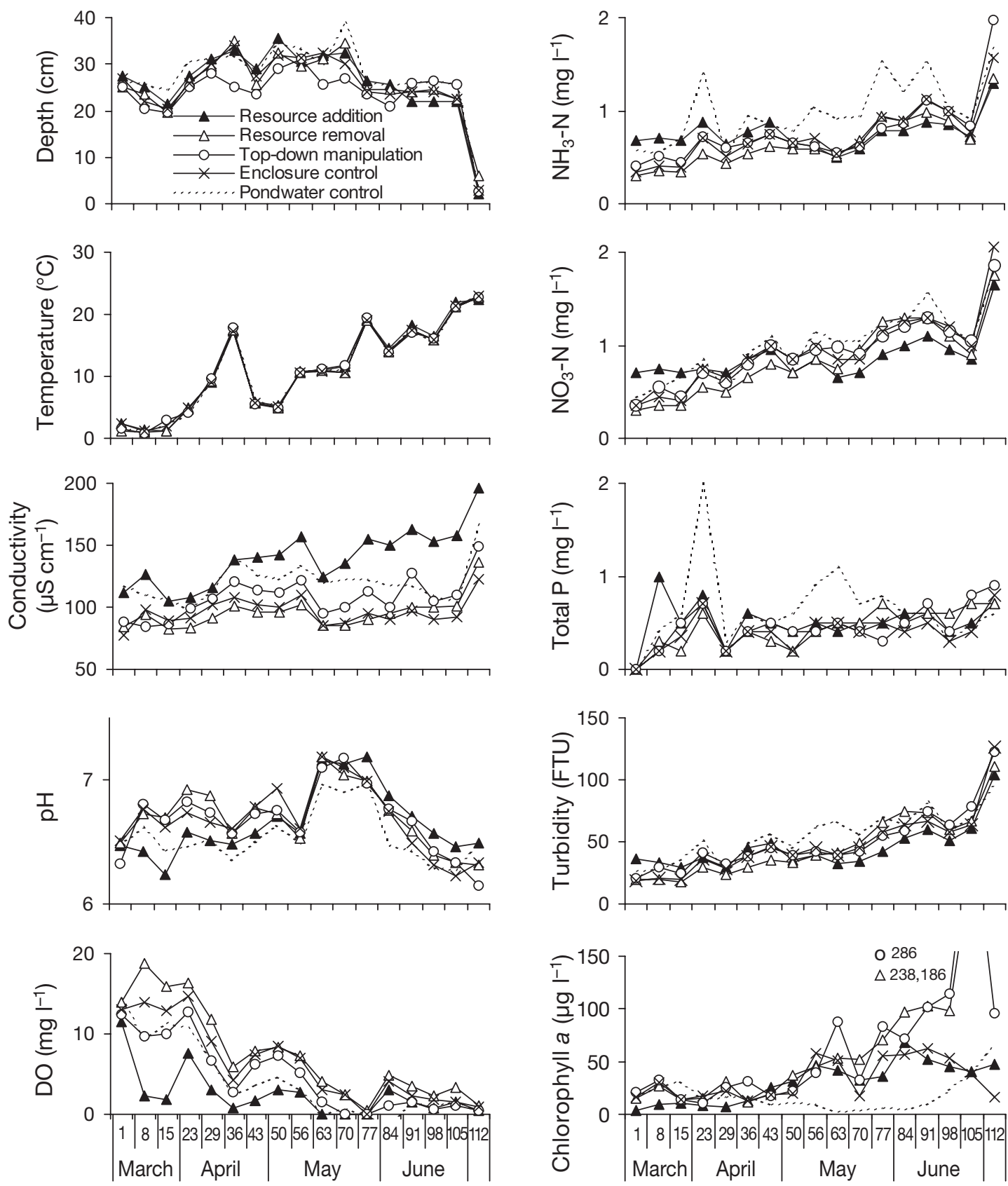

Month and days after flooding

Fig. 1. Seasonal variation in physicochemical parameters in Pond I (mean, $n=2$ )

progressed in both ponds, reaching maxima of 15 to $23^{\circ} \mathrm{C}$ (higher in Pond I, Figs. 1 \& 2). Turbidity, nitrate, and ammonia were generally higher in Pond I, whereas $\mathrm{pH}$ and conductivity were higher in Pond II ( $p<0.001$, main pond effect, ANOVAR). The nutrients slowly increased with time in both ponds (pondwater controls) until they reached maxima prior to drying (Figs. 1 \& 2). In Pond II, a drop in these variables on Day 64 was related to unusually high water depth.
Dissolved oxygen (DO) decreased with time in both ponds (but had a higher initial concentration in Pond I, Figs. $1 \& 2, \mathrm{p}<0.0001$, time $\times$ pond effect, ANOVAR). Chl a ranged between 3 and $66 \mu \mathrm{g} \mathrm{l}^{-1}$ in Pond I, and between 4 and $163 \mu \mathrm{g} \mathrm{l}^{-1}$ in Pond II (pondwater controls), and peaked during the days prior to drying.

Compared with the pondwater controls, the enclosure controls had lower total phosphorus $(-31 \%$ and $-19 \%$ in Ponds I and II, respectively), higher chl a 

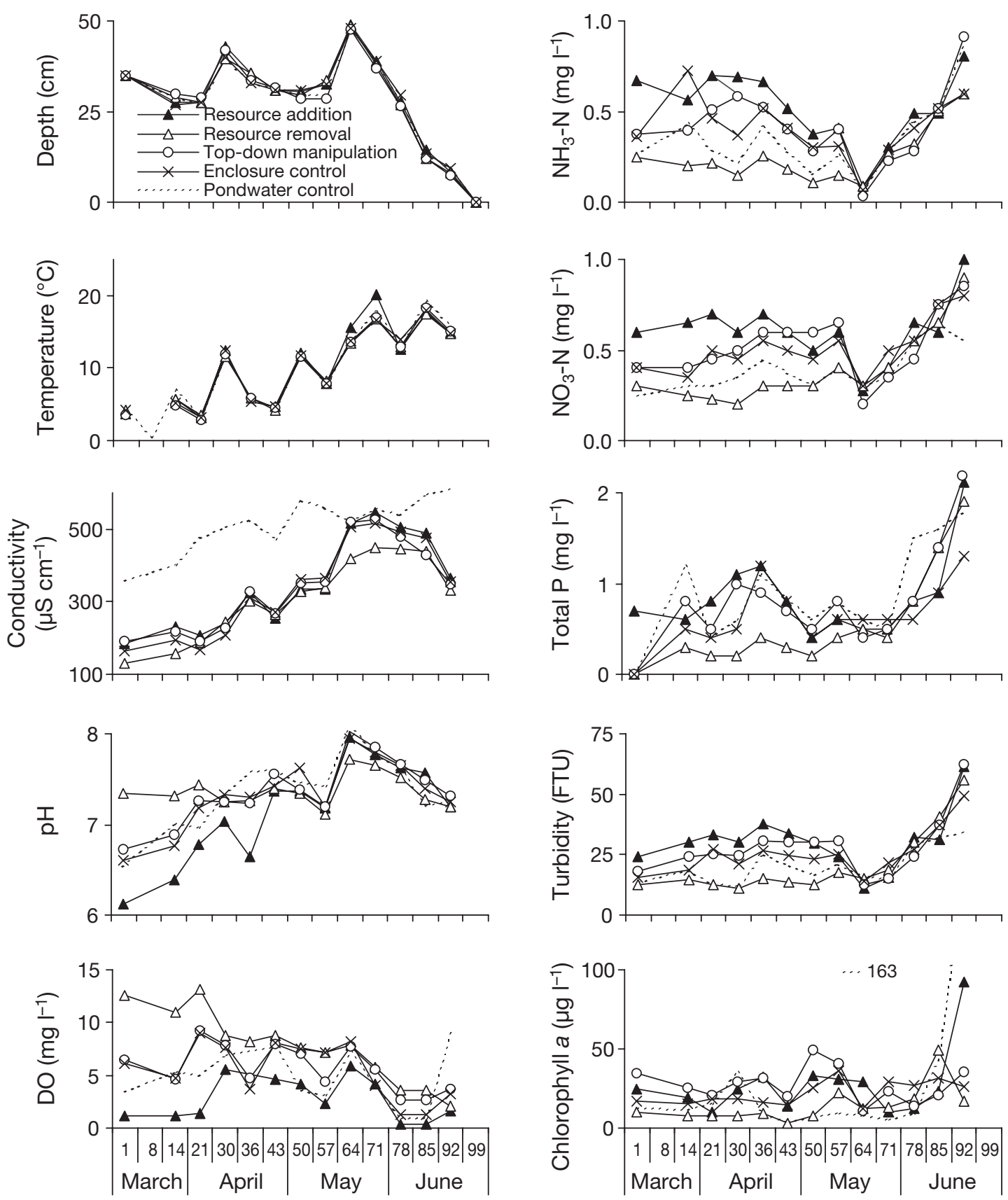

Month and days after flooding

Fig. 2. Seasonal variation in physicochemical parameters in Pond II (mean, n = 2)

$(+300 \%$ and $+120 \%)$, lower ammonia in Pond I $(-26 \%)$, and lower conductivity in Pond II $(-36 \%, \mathrm{p}<$ 0.001 , planned comparison of pond $\times$ treatment effects, ANOVAR, Figs. $1 \& 2$ ). The resource addition resulted in higher nitrate $(+50 \%$ in early season in both ponds), phosphorus $(+70 \%$ and $+40 \%$ in early-mid season in Ponds I and II), turbidity ( $+43 \%$ in early season), and conductivity in Pond I $(+46 \%)$, but lower DO $(-59 \%$ and $-67 \%$ in Ponds I and II) and $\mathrm{pH}(-0.2$ units in early-mid season in both ponds). The resource removal resulted in higher DO $(+20 \%$ and $+70 \%$ in early season in Ponds I and II) and lower nitrate $(-20 \%$ and $-39 \%$ ). In Pond $\mathrm{II}$, the same treatment resulted in higher $\mathrm{pH}(+0.37$ units in early season), but lower ammonia (-55\% in early-mid-season), total phosphorus $(-46 \%$ early-mid-season), and chl a $(-55 \%)$. The top-down manipulation did not significantly affect any physicochemical variables ( $p>0.01)$. 


\section{The biota}

The bacterial abundance in the water column of the pondwater controls ranged from 1.2 to $4.8 \times 10^{6} \mathrm{ml}^{-1}$ in Pond I, and 1.1 to $5.5 \times 10^{6} \mathrm{ml}^{-1}$ in Pond II (Fig. 3), and was 70 and $100 \%$ higher within the enclosures (Ponds I and II, respectively, $\mathrm{p}<0.01$, planned contrast of main treatment effect). The resource addition resulted in a 100 vs. $40 \%$ higher bacterial abundance compared with the control enclosures (in Ponds I and II), whereas the resource removal resulted in a 30 vs. $70 \%$ reduction (early-mid season in Ponds I and II, p < 0.005).

Crustaceans were more common in Pond II than in Pond I $\left(p<0.005, F_{1,10}=18.1\right.$, pond effect ANOVAR), whereas flagellates and amoebae were more common in Pond I ( $p<0.05, F_{1,10}=7.1$, Fig. $\left.4 \mathrm{a}\right)$. The enclosures prevented the occurrence of cladocerans in Pond I and reduced ostracods in Pond II (Fig. 4b). Crustaceans peaked in April in both ponds $\left(\mathrm{p}<0.0001, F_{12,120}=8.1\right.$, time effect ANOVAR, Fig. 4c), and in early season the abundance of crustaceans was lower within the enclosures compared with the outside pondwater in Pond II ( $p<0.0001$, planned contrast of treatment $\times$ time effect ANOVAR). The resource addition resulted in an increase of crustaceans in Pond II compared with the enclosure controls (mid-, and late-season, $\mathrm{p}<0.005$ ). The resource removal resulted in more flagellates and amoebae in Pond I (late-season, p < 0.0001) and more algal cells (late-season, $\mathrm{p}<0.0005$ ) and crustaceans in Pond II (mid-season, $\mathrm{p}<0.0005$ ). The top-down manipulation enclosures produced a lower occurrence of crustaceans in Pond I (early-, and mid-season, $\mathrm{p}<0.05$ ) and fewer flagellates and amoebae in Pond II (lateseason, $\mathrm{p}<0.005)$.

\section{Species composition and abundance}

Full data on the occurrence of cliates in the ponds are given in Appendix 1. The number of ciliate species each week ranged from 5 to 36 in Pond I and 10 to 33 in Pond II (average, $\mathrm{n}=2$, Fig. 5a), and was higher within the enclosures than outside (mid-season, p < 0.001, planned contrast, ANOVAR, Table 1). The cumulative number of species in the pondwater controls was 74 in Pond I (58 \pm 2 per site, mean $\pm 1 \mathrm{SD}, \mathrm{n}=$ $2)$ and 72 in Pond II $(62 \pm 1)$. The enclosures added 47 more species to Pond I and 34 species to Pond II: resulting in $61 \pm 2$ vs. $50 \pm 2$ species in the enclosure controls (Pond I and II respectively); $75 \pm 5$ vs. $57 \pm 10$ in the resource additions; $59 \pm 11$ vs. $45 \pm 2$ in the resource removals; and $54 \pm 1$ vs. $58 \pm 2$ in the top-down manipulations. Of the total 162 species in the 2 ponds combined (43\% Kinetofragminophora species, 36\% Polyhymenophora, and $21 \%$ Oligohymenophora species, based on the macrosystem of Corliss 1979), 65 species $(40 \%)$ occurred in both ponds. $58 \%$ of the species in Pond I and $72 \%$ of the species in Pond II were present in both replicates. Persistent species (i.e. those present during the entire hydroperiod) comprised $\sim 15 \%$ of the ciliates, whereas $25 \%$ of the species occurred sporadically (i.e. appeared in only 1 or 2 of the weeks).

Total ciliate abundance (Fig. 5b) was significantly higher and Shannon's diversity index lower (Fig. 5c) in Pond I compared with Pond II ( $\mathrm{p}<0.05$, Main pond effect ANOVAR, Table 1). Ciliate abundance in the pondwater controls (i.e. outside the enclosures) was usually below 5 to 10 cells $\mathrm{ml}^{-1}$, and peaked early and late in the hydroperiods (maxima of 49 cells $\mathrm{ml}^{-1}$ in Pond I, and 89 cells $\mathrm{ml}^{-1}$ in Pond II). Total ciliate abundance in Pond I enclosures followed the pattern observed in the pondwater controls for the first $29 \mathrm{~d}$. Thereafter, ciliate abundance inside the enclosures exceeded that of the pond water considerably, primarily due to small ciliates (peaking at $\sim 102$ cells $\mathrm{ml}^{-1}, \mathrm{p}<$ $0.001)$. Thus, the resource addition resulted in higher

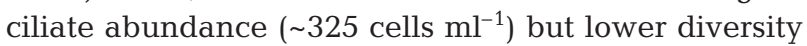
(Shannon's diversity index) in Pond I (mid-season, p < 0.0005, Fig. 5c). Abundances in the resource removal and top-down (partial predator removal) treatments did not differ significantly from the enclosure controls in any of the ponds.

The pondwater controls in Pond I were dominated by small $(<50 \mu \mathrm{m}$, indicated as size group '1' in Appendix 1) Urotricha and Cyclidium species, which made up 9 to $95 \%$ of the total community (numerically) throughout the hydroperiod (average 50\%). Most mediumsized species (50-200 $\mu \mathrm{m}$, group '2') belonged to Hypotricha. Although large $(>200 \mu \mathrm{m})$ species, such as those belonging to Pleurotricha, Spirostomum, and Stentor, were generally less common, they contributed significantly to overall ciliate biomass by virtue of their size (especially $S$. ambiguum). In Pond II, the small species of Urotricha and Cyclidium were less dominant than in Pond I, but still made up 5 to $54 \%$ (average $24 \%$ ) of the total ciliate abundance. Other small-sized ciliates that occasionally contributed to more than $10 \%$ of the total abundance in Pond II included Vorticella, Chilodonella, and Halteria. Strobilidium and Metopus species were the most abundant medium-sized ciliates in Pond II, whereas large-sized ciliates were poorly represented. A distinctive feature of Pond II was the appearance and predominance of representatives of the order Hypotricha before drying: especially the genera Keronopsis, Oxytricha, Stichotricha, Stylonychia, Tachysoma, and Uroleptus.

Small ciliates also dominated inside the enclosures in Pond I throughout the hydroperiod (with peaks in May to June, Fig. 6a). In the resource additions of Pond I, small-sized species initially made up only $30 \%$ of the 

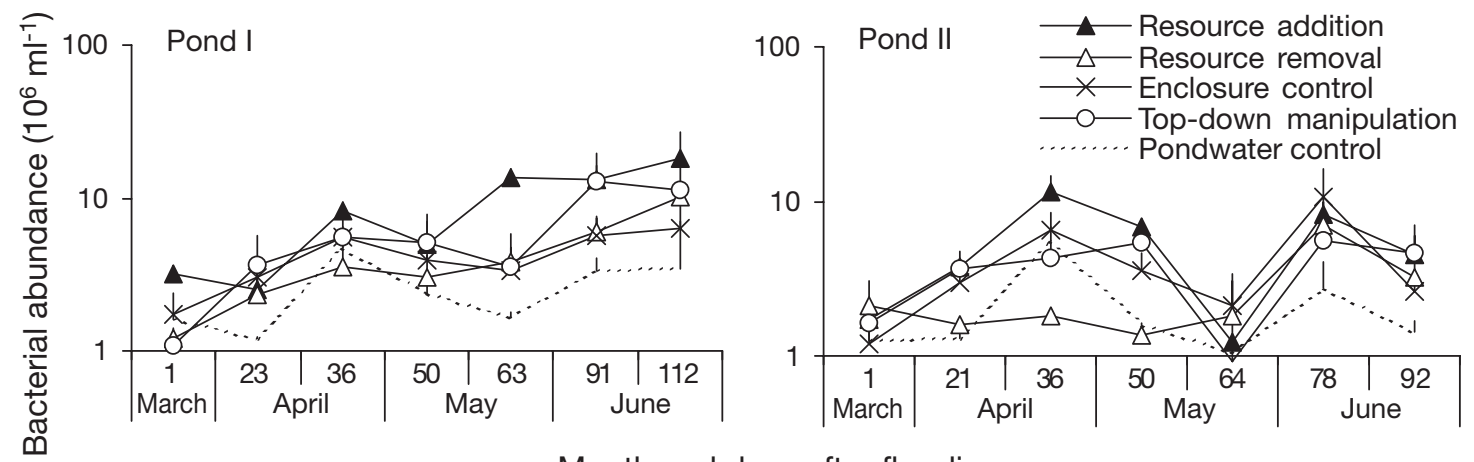

Month and days after flooding

Fig. 3. Bacterial development in the different treatments in the ponds (means $+1 \mathrm{SD}, \mathrm{n}=2$ )
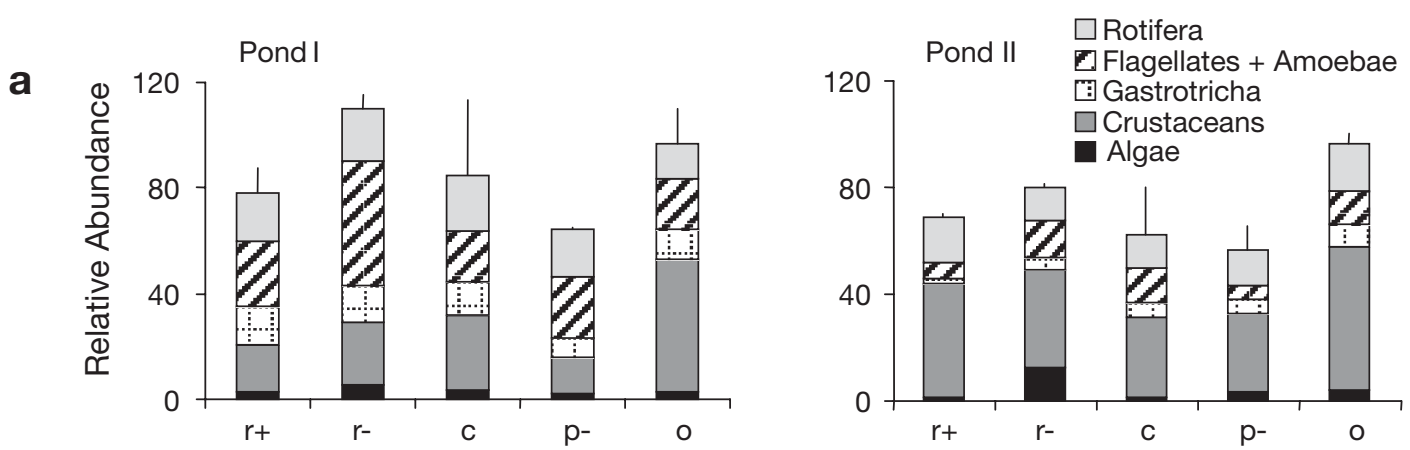

b
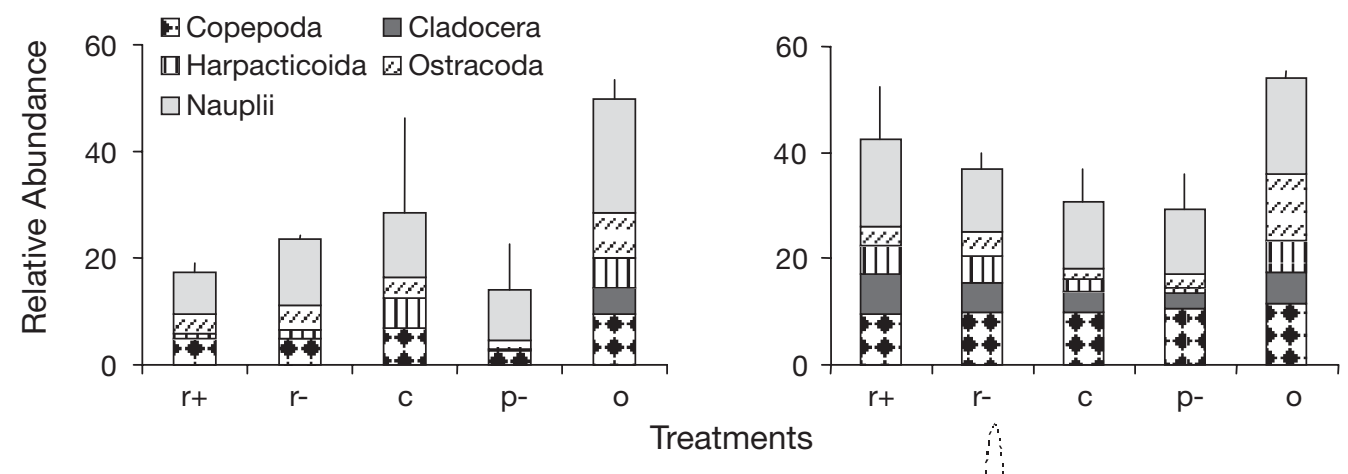

C
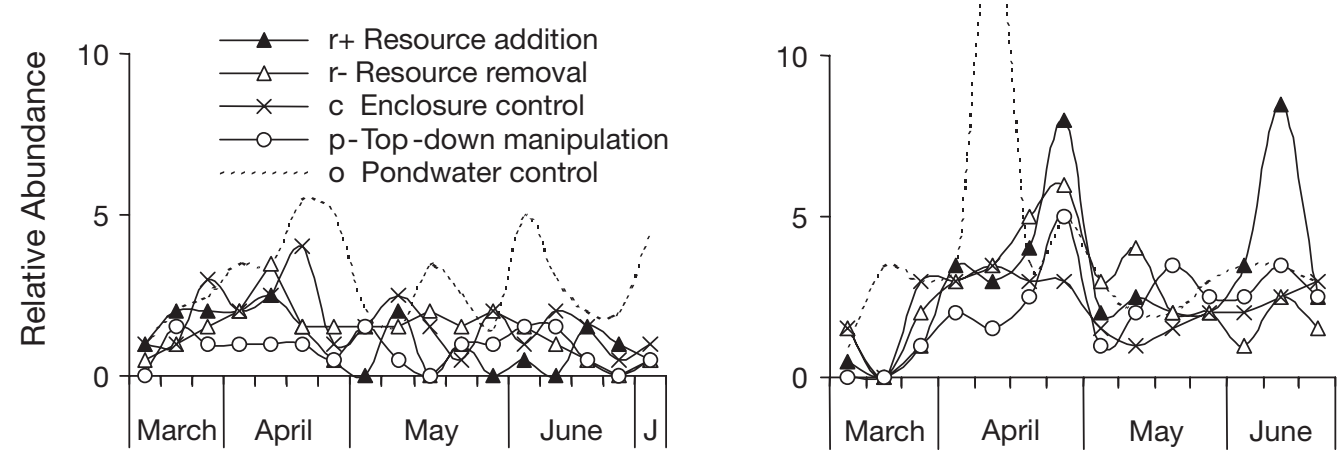

Month

Fig. 4. (a) Relative abundance of major taxonomical groups from all dates combined (means $+1 \mathrm{SD}, \mathrm{n}=2$ ) within each treatment, (b) major crustacean groups, and (c) seasonal development of the crustaceans (means, $\mathrm{n}=2$ ) within each treatment: Figures are based on semi-quantitative abundance (abundant $=4$, present $=1$, absent $=0$ ) 

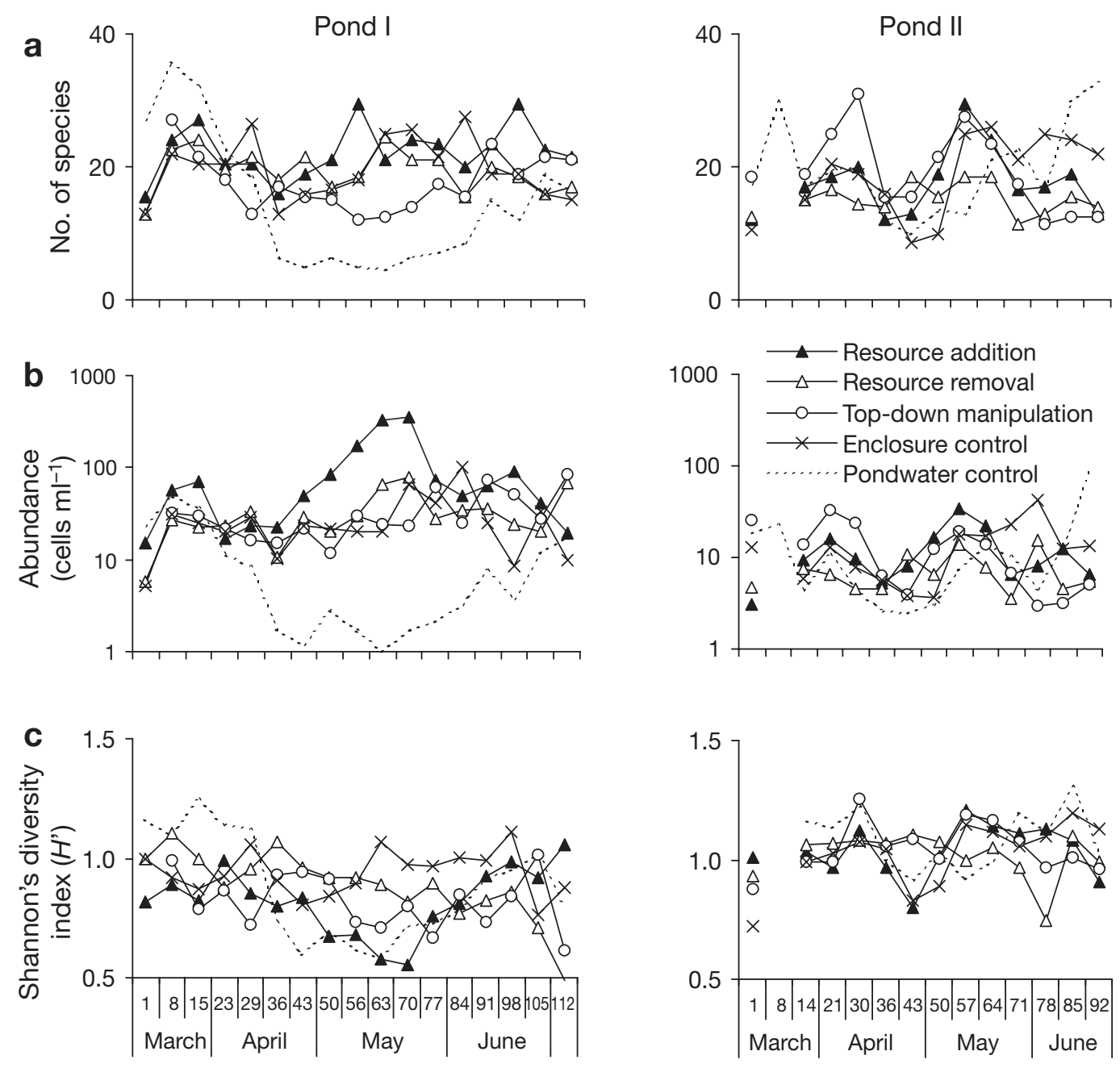

Month and days after flooding

Fig. 5. Seasonal development of (a) number of ciliate species, (b) ciliate abundance, and (c) Shannon's diversity index (means, $\mathrm{n}=2$ )

community (compared with $80 \%$ in the enclosure control, $\mathrm{p}<0.0021$, planned contrast of time $\times$ pond $\times$ treatment interaction, ANOVAR, Table 1, and Fig. 6b), but dominated the community from mid April to late May (80 to $97 \%$ ), which was higher than in the enclosure controls (50 to $86 \%, \mathrm{p}<0.0021$ ). The peak of small-sized ciliates comprised Cyclidium glaucoma ( 260 cells ml $\left.{ }^{-1}\right)$, Urotricha farcta, U. furcata, and Halteria grandinella. The medium-sized species were less abundant than the smaller size group, but showed a distinct seasonal pattern in the resource addition: Colpidium kleini $\left(37\right.$ cells $\mathrm{ml}^{-1}$ ) and C. colpoda peaked at the beginning of the hydroperiod, and Pelagolacrymaria rostrata (40 cells $\mathrm{ml}^{-1}$ ) in the middle. Large-sized Paramecium caudatum and medium-sized Vorticella species dominated prior to drying. The leaf-litter addition was the treatment that most affected the ciliate community composition (i.e. the $r+$ has the longest arrow in Fig. 7b). The leaf-litter removal resulted in increasing abundance in some species (see 'Discussion' and Fig. 7b). The top-down manipulation did not influence the ciliate community composition significantly (the arrow of $\mathrm{p}$ - is close to $\mathrm{c}$ in Fig. 7b), except for a $+20 \%$ increase in the dominance of Urotricha and Cyclidium species in Pond I.

\section{Ciliate feeding groups}

Most ciliate species in the ponds feed on bacteria and algae (except diatoms, but inclusive of autotrophic flagellates; prey preferences of each ciliate are noted in the 'prey' column in Appendix 1; based on Foissner \& Berger 1996). On average, one-third of the ciliate species were bacterio-algivores, one-tenth facultative bacterivores, $15 \%$ predators (feeding on 
Table 1. Results (F-values and ${ }^{*}$ indicating statistical significance) of repeated measures ANOVA, of treatment and pond effects on ciliate community properties. Statistical significant p-values are indicated by asterisks $\left({ }^{*} \mathrm{p}<0.05 ;{ }^{* *} \mathrm{p}<0.01 ;{ }^{* * *} \mathrm{p}<0.001 ; G\right.$ $G$ adjusted for all interaction effects). Below significant $F$-values, the outcome of Bonferroni corrected planned contrasts are summarized in italics (Pond I [I], Pond II [II]; early-, mid-, late season; control enclosure [c]. pondwater control [o], resource addition $[\mathrm{r}+]$, and resource removal $[\mathrm{r}-]_{\text {; }}$ non-significant $\left.[\mathrm{ns}]\right)$. Mean square (MS) values of residuals are given for main effects and interaction effects

\begin{tabular}{|c|c|c|c|c|c|c|c|c|c|}
\hline & df & $\begin{array}{l}\text { Critical } \\
p_{\text {post-hoc }}\end{array}$ & Abundance & $\begin{array}{l}\text { Number } \\
\text { of species }\end{array}$ & $H^{\prime}$ & $\begin{array}{l}\text { Size group } 1 \\
\quad<50 \mu \mathrm{m}\end{array}$ & Algivores & $\begin{array}{c}\text { Facultative } \\
\text { bacterivores }\end{array}$ & Omnivores \\
\hline \multicolumn{10}{|l|}{ Main effects } \\
\hline Pond & 1 & 0.05 & $\begin{array}{l}25.11^{* * *} \\
I>I I\end{array}$ & 0.018 & $\begin{array}{l}65.29^{* * *} \\
I I>I\end{array}$ & $\begin{array}{l}82.81^{* * *} \\
I>I I\end{array}$ & $\begin{array}{l}13.9^{* *} \\
I>I I\end{array}$ & $\begin{array}{l}51.25^{* * *} \\
I>I I\end{array}$ & $\begin{array}{l}64.7^{* * *} \\
I I>I\end{array}$ \\
\hline Treatment & 4 & 0.0125 & $\begin{array}{l}8.67^{* *} \\
o<C\end{array}$ & 1.93 & 1.45 & 1.89 & $\begin{array}{c}6.87^{* *} \\
r+<C\end{array}$ & $\begin{array}{l}13.05^{* * *} \\
r+>C\end{array}$ & 2.48 \\
\hline $\begin{array}{l}\text { Pond } \\
\times \text { Treatment }\end{array}$ & 4 & 0.0063 & $\begin{array}{l}7.22^{* *} \\
o_{I}<C_{I}\end{array}$ & $\begin{array}{c}4.01^{*} \\
o_{I}<C_{I}\end{array}$ & 0.15 & 1.27 & $\begin{array}{l}4.02^{*} \\
\mathrm{~ns}\end{array}$ & 1.62 & 3.12 \\
\hline MS error & 10 & & 0.322 & 68.39 & 0.037 & 346 & 271 & 136 & 159.9 \\
\hline \multicolumn{10}{|c|}{ Interaction effects } \\
\hline Time & 12 & & $6.00^{* * *}$ & $4.74^{*}$ & $3.00^{* *}$ & $3.93^{* *}$ & 1.83 & $3.65^{* *}$ & 1.02 \\
\hline $\begin{array}{l}\text { Time } \\
\times \text { Pond }\end{array}$ & 12 & 0.0083 & $2.96^{*}$ & 2.75 & $2.8^{* *}$ & $\begin{array}{c}9.15^{* * *} \\
I_{\text {mid-late }}>I I\end{array}$ & 1.85 & 1.33 & 2.27 \\
\hline $\begin{array}{l}\text { Time } \\
\times \text { Treatment }\end{array}$ & 48 & 0.0042 & $\begin{array}{c}3.29^{* * *} \\
r+_{\text {mid }}>C>o_{\text {mid }}\end{array}$ & $\begin{array}{c}2.51^{*} \\
o_{\text {mid }}<C\end{array}$ & $\begin{array}{c}2.19^{* * *} \\
r++_{\text {mid-late }}<C \\
o_{\text {mid }}<C\end{array}$ & $\begin{array}{c}3.09^{* *} \\
r++_{e a r l y}<C\end{array}$ & $\begin{array}{l}2.50^{* *} \\
\mathrm{~ns}\end{array}$ & $1.75^{*}$ & 1.82 \\
\hline $\begin{array}{l}\text { Time } \\
\times \text { Pond } \\
\times \text { Treatment }\end{array}$ & 48 & 0.0021 & $\begin{array}{c}3.14^{* *} \\
r+{ }_{I, \text { mid }}> \\
C>O_{I, \text { med }}\end{array}$ & 1.74 & 1.40 & $\begin{array}{c}1.99^{*} \\
O, r+{ }_{I, \text { early }}<C \\
r+{ }_{I, \text { mid }}>C\end{array}$ & $\begin{array}{c}1.94^{*} \\
n s\end{array}$ & $\begin{array}{c}2.73^{* *} \\
r+_{I, I I, \text { mid }}>C \\
r-{ }_{I, \text { mid }}<C\end{array}$ & 1.02 \\
\hline MS error & 120 & & 0.07 & 24.53 & 0.015 & 143 & 118 & 91 & 66.8 \\
\hline
\end{tabular}

protozoans, mostly ciliates, and small metazoans), and $17 \%$ omnivorous (i.e. feeding on autotrophic organisms, small protozoans and metazoans). In Pond I the algivores comprised $58 \%$ of the total ciliate abundance $(50 \%$ in Pond II), whereas $92 \%$ were bacterivores $(78 \%$ in Pond II), $28 \%$ facultative bacterivores (17\% in Pond II), $4 \%$ were omnivores (16\% in Pond II), and less than $2 \%$ were predators (in both ponds; Fig. $6 a, b, p<0.01$, pond effect ANOVAR). In midhydroperiod, the proportion of facultative bacterivores increased with $\sim 15 \%$ in the resource addition in both ponds, and decreased with the same percentage in the resource removal $(p<0.01)$. The proportion of algivores followed the seasonal trend in phytoplankton (as measured by chl a, Figs. 1 \& 2). There were few facultative algivores in either pond (usually less than $5 \%$ ) although their abundances increased as the ponds dried up (e.g. Uroleptus gallina in Pond II and Pelagohalteria cirrifera in Pond I). The most abundant representatives of omnivorous ciliates belonged to the
Hypotricha. In addition, the omnivore Oxytricha hymenostoma was very abundant in Pond II prior to drying (Fig. 6a). Predatory ciliates peaked at the beginning of the hydroperiod especially in Pond I, then declined in the middle and increased again slightly prior to dry-up.

\section{Environmental influence on community characteristics}

Ciliate abundance (log) and the species richness from all enclosures and outside were combined into a larger dataset for analysis of the possible influence of environmental factors (i.e. the 'global solution'). In both ponds combined, the environmental variables together with pond identity and treatment explained $49 \%$ of ciliate abundance (stepwise linear regression, $\log [$ abundance $]=0.94+0.55 \mathrm{chl} a+0.35$ 'resource addition' -0.33 Pond; $F_{11,119}=11.12$, p $<0.001$ ), and 

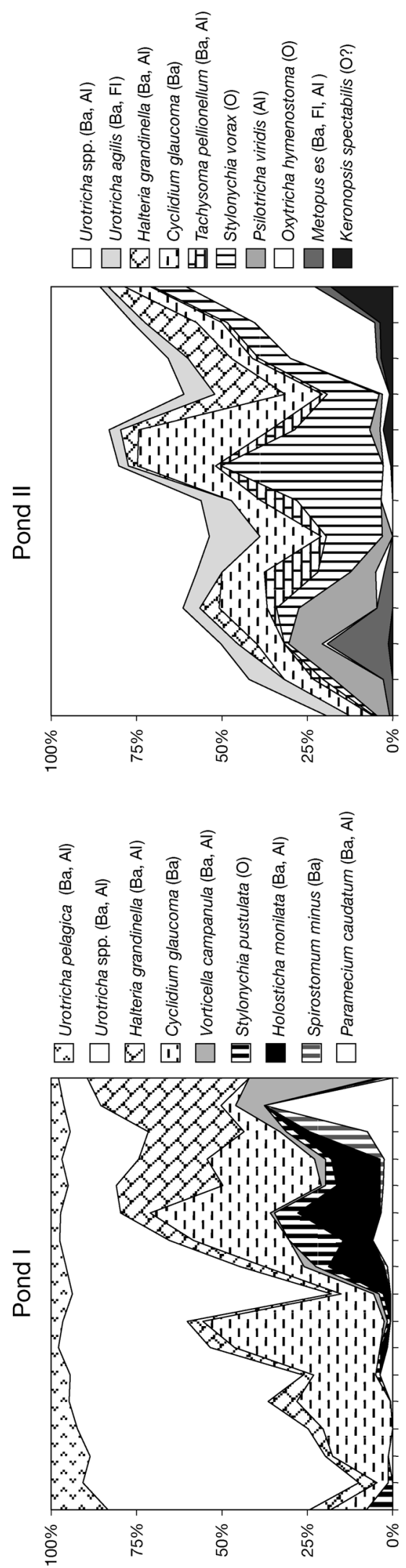

(ర
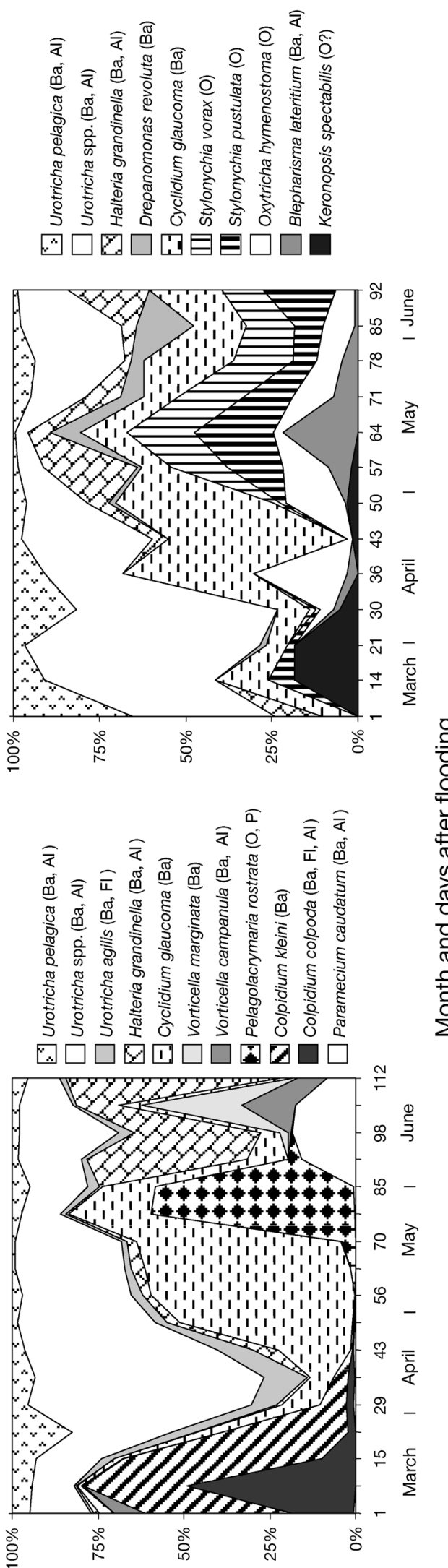

อ

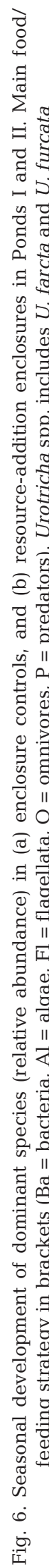


a

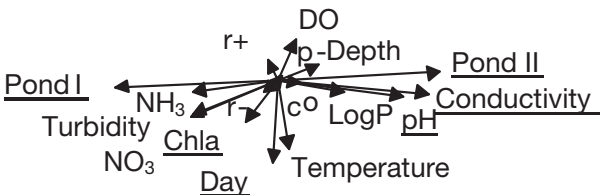

\section{b}
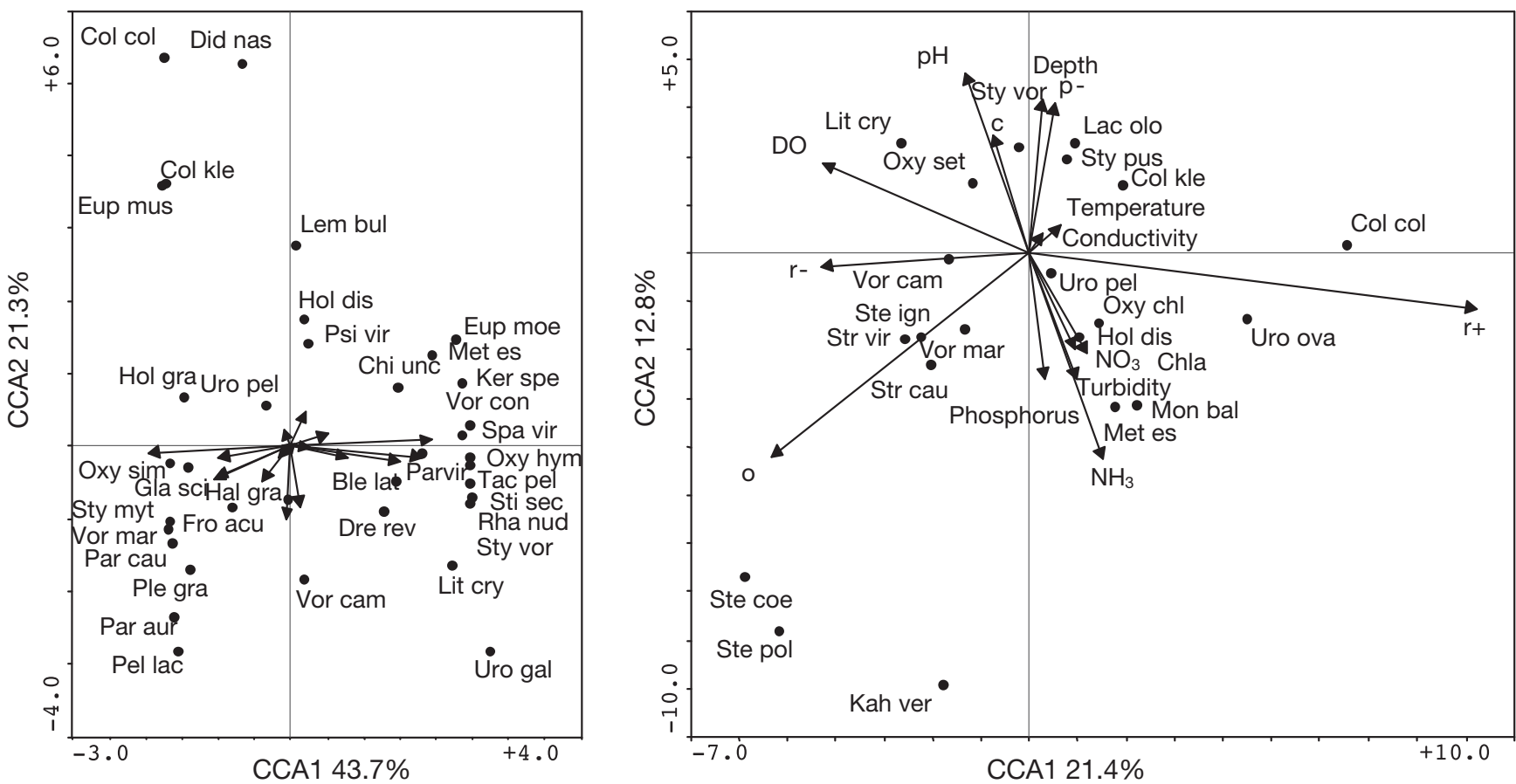

Fig. 7. Species-environment biplot diagram from the CCA with (a) the whole dataset in the lower diagram (species with lower than $10 \%$ fit are not shown; the abbreviated species names correspond to the species in bold in Appendix 1), and the projection of environmental variables in the upper diagram (most important variables are underlined), and (b) the same data set but with Pond and Days after flooding as covariables (species with lower than $5 \%$ fit are not shown; the abbreviated species names correspond to the underlined species in Appendix 1)

$34 \%$ of the species diversity index $\left(\mathrm{H}^{\prime}=0.41+0.39\right.$ LogDO + 0.29Pond -0.25 'resource addition' -0.21 'top-down manipulation'; $F_{11,119}=5.59, \mathrm{p}<0.0001$ ). When the same analysis was done on each pond separately, the environmental variables and treatments explained 62 vs. $32 \%$ of the ciliate abundance (in Ponds I and II, respectively); and 31 vs. $24 \%$ of the species diversity (in Pond I and II; DO was the most important factor in Pond I and $\mathrm{pH}$ in Pond II).

One-fifth of the total variation in the ciliate species data $(22.2 \%)$ could be summarized by 4 axes in the unconstrained ordination. The measured environmental variables accounted for most of this variation (CCA, $\mathrm{p}=0.005)$. The CCA axes represented a pond gradient ( $43.7 \%$; i.e. pond, $\mathrm{pH}$, and conductivity, Fig. $7 \mathrm{a}$ ), a season gradient $(13.5 \%$; i.e. days after flooding and chl $a$, Fig. 7a), a bottom-up gradient $(9.3 \%$; resource addition, resource removal), and a top-down gradient (5.6\%; top-down manipulation, and water depth). The species-environment correlation in each CCA axes was $0.96,0.85,0.80$, and 0.73 respectively. The treatment effects were further explored in a second CCA with pond and days after flooding as covariables (Fig. $7 b$ ). In this analysis, $21.4 \%$ of this variation could be explained by a bottom-up gradient (resource addition versus resource removal, pondwater control, and DO) and $12.8 \%$ by a top-down/productivity gradient (top-down manipulation and enclosure control versus nutrients and pondwater control). The 2 following axes were a temperature/DO/resource removal gradient $(10 \%)$ and a $\mathrm{pH}$ gradient $(9.6 \%)$. The species environmental correlations were $0.80,0.75,0.71$, and 0.65 . Similar gradients were found when the CCA was run on each pond separately (data not shown but differences in species assemblages are addressed in the 'Discussion'). Furthermore, rotifers and zooplankton predators had weak correlations with ciliate community composition, when added as 2 independent variables in the CCA (for simplicity these variables are not shown in the figures). 


\section{DISCUSSION}

Ciliates provide an important link between resources and higher trophic levels in many fresh waters. They are key organisms in many freshwater food webs and could potentially absorb and reflect any perturbations; hence, ciliates are highly suitable for studying community regulating processes such as topdown and bottom-up control. The relative importance of top-down and bottom-up mechanisms is thought to change along the habitat duration gradient, but also depends on the species composition of both the prey and the predator communities. Intermittent ponds, which are near the extreme short end of the habitat duration gradient, are characterized by rapid changes in abiotic and biotic factors and the importance of bottom-up and top-down control is considered to be relatively low. However, this has not been well studied in the field.

\section{Natural development of ciliates}

Total ciliate abundance, number of species, and diversity showed a bimodal seasonal distribution in the pondwater controls, with maxima in spring and late summer. The peak in early spring coincided with raised temperature and release of nutrients from decomposition of dead aquatic vegetation and riparian leaf litter, whereas the peak prior to drying was a concentration effect caused by the shrinking water volume. The lower ciliate abundance and diversity in mid-hydroperiod co-occurred with low phytoplankton concentrations, and with higher abundance of crustaceans (peaked in mid-late April). The ciliate communities underwent rapid species succession and contained many rare species (temporally and spatially, Andrushchyshyn et al. 2003, this study). The low overlap in ciliate species composition between the 2 intermittent ponds suggests that, although ciliates may have cosmopolitan distributions (Finlay \& Fenchel 2004), species composition in adjacent habitats can vary considerably. Moreover, despite the visual and measured homogeneous appearance of each pond (in terms of within-pond depth, substrate, water chemistry, light regime, and macrophyte composition), the spatial heterogeneity of ciliate populations within each pond was pronounced (one-third of the species present occurred in only 1 of 2 replicates). Such variation could be related to continuous reciprocal interactions with the environment, alongside the ability of ciliates to quickly and repeatedly exploit suitable, and novel, niches (e.g. Finlay \& Esteban 1998b) — as where, for example, the species counts rose in the Vandorf enclosures compared with the pondwater itself.

\section{Influential factors}

The spatial and temporal distributions of ciliates are usually governed by seasonal factors, by temporal and spatial availability of food and habitat resources, by the distribution of oxygen, and by competition and predator-prey relations (e.g. Bick 1973, Kusano et al. 1987, review by Beaver \& Crisman 1989, Guhl et al. 1994). Several of these factors were influential for the ciliate community structure in Vandorf ponds: the measured environmental variables (including pond and treatments) accounted for half of the variation in ciliate abundance, one-third of the species diversity, and one-fifth of the community composition. Ciliate abundance and diversity were best explained by pond characteristics and the leaf litter addition treatment. The most influential factors, however, were chl a for ciliate abundance, and dissolved oxygen for species diversity. Ciliate community composition was best explained by pond characteristics, followed by season and treatment.

The differences in ciliate species composition between the 2 ponds could be attributed to differences in food availability and vegetation structure (mixed emergent, submergent, and floating plants in Pond I, but mainly Phalaris sp. in Pond II); water chemistry (e.g. higher levels of nitrogen and turbidity in Pond I, and higher $\mathrm{pH}$, conductivity, and DO in Pond II); and predation pressure (zooplankton density was higher in Pond II). For example, an overall higher bacterial abundance in Pond I was accompanied by higher occurrence of ciliate bacterivores, and the facultative bacterivores in Pond I comprised 6 species with a total abundance 20 times higher than in Pond II, which had 9 species of facultative bacterivores. The lower abundance of ciliates in Pond II compared with Pond I was likely coupled to predation pressure because zooplankton (e.g. cladocera and harpacticoids) and omnivorous hypotricha species (which potentially feed on small-sized ciliates) were more abundant in Pond II than in Pond I. Several previous studies have reported tight correlation between the abundances of zooplankton predators and ciliates (Gilbert 1989, review by Stoecker \& Capuzzo 1990, Pace \& Funke 1991, Gilbert \& Jack 1993, Sanders \& Wickham 1993, Sipura et al. 2003).

The seasonal development of ciliate community composition in the ponds was strong and correlated with the increasing temperatures. The seasonal change in the relative feeding groups reflected changes in food composition and abundance (leaf litter, detritus, bacteria), whereas the change in size distribution indicated selective predation by zooplankton, and other ciliates. In addition, light availability mostly restricted the distribution of species containing symbi- 
otic algae (e.g. some species in the genera Strombidium, Halteria, Loxodes, Stichotricha, Oxytricha, and Paraurostyla) to early in the hydroperiod before turbidity increased in the ponds, and the high density of Hypotricha (most of them contain symbiotic zoochlorellae) in Pond II (which was less turbid than Pond I).

\section{Treatment effects}

The use of enclosures led to higher species richness and ciliate abundance, possibly due to more favourable physicochemical environments, and/or by broadening the range of niches available, by restricting movement of zooplankton predators, and by the cumulative effect of the ciliates themselves.

Although the importance of leaf litter decomposition for bacteria and protist abundance can be strong in ponds (Hatano \& Watanabe 1981, Kusano et al. 1987), many studies suggest that the addition of resources or nutrients can have weak effects on protists due to indirect effects, interactions with other zooplankton, predation (especially by Daphnia), and internal feedback mechanisms (Pace \& Funke 1991, Havens \& Beaver 1997, Marchessault \& Masumder 1997, Hillebrand et al. 2002). However, the addition of leaf litter was the treatment that had most influence on the ciliate community in the Vandorf ponds. This treatment increased total ciliate abundance significantly (especially smallsized ciliates in mid-season), and affected ciliate community composition. In Pond I, this treatment resulted in the appearance of 11 rare species and 2 abundant species (Urotricha ovata and Colpidium colpoda). Some of these species possibly originated from cysts introduced with riparian leaf litter. Moreover, some species (e.g. Cyclidium glaucoma, Urotricha farcta, U. furcata, and Halteria grandinella) attained very high densities in this treatment, especially early in the hydroperiod and coincided with increasing temperatures and decomposition of terrestrial material. Several species within the genera Colpidium, Frontonia, Loxodes, Metopus, Spirostomum, and Stentor are known to survive well in low oxygen environments (Foissner \& Berger 1996), and the contribution of these taxa was considerably higher when oxygen levels were low in the resource addition in Pond I (especially early in the hydroperiod). In addition, the increase of small ciliates was accompanied by an increase of medium-sized Pelagolacrymaria rostrata (peaked in abundance during Days 75 to 85) - a predator that feeds on Urotricha and oligotrichs (Foissner et al. 1999). In Pond II, the resource additions affected ciliate abundance at times, but had less influence on the species composition. However, medium-sized bacterivores (especially Colpidium kleini and C. colpoda) peaked during the first
3 wk after snowmelt in this treatment. Thus, the effects of the resource addition differed between the 2 ponds, suggesting that the outcome of food web manipulations was more related to differences in abiotic and biotic factors than to habitat proximity.

Since leaf-litter is not a direct food resource for ciliates, treatment effects were likely mediated by alterations in the habitat and in food composition. The addition of leaf litter resulted in higher bacterial abundance in the water column, higher nutrient concentrations, and lower dissolved oxygen (due to increasing decomposition), which was accompanied by an increasing dominance of ciliate bacterivores (which sometimes comprised 60 to $85 \%$ of the ciliates). These results agree with the finding of Hatano \& Watanabe (1981), who showed a strong relationship between bacterivore protists and leaf-litter decomposition in permanent ponds.

The resource removal resulted in decreasing levels of nutrients and bacteria, and a lower proportion of ciliate bacterivores in Pond I. Ciliate abundance and species richness also tended to be lower in this treatment than in the enclosure controls, however, these effects were not statistically significant. Other effects included higher biomass of the large species of Holophrya and Stentor in Pond I, and some species of Vorticella in Pond II. Also, the abundance of Halteria, Strobilidium, and Strombidium increased when leaf and plant litter were removed. These taxa are either algivorous or contain symbiotic algae which keeps them directed towards light, thus an increase in these species may be attributed to the lower turbidity in this treatment compared with the enclosure controls.

The top-down manipulation excluded the entry of aerially colonizing insects (e.g. culicids, chironomids, and Chaoborus) whose larvae could feed directly upon ciliates and potentially have a substantial effect on their prey communities (review in Sanders \& Wickham 1993). The nets also excluded Coleoptera and Odonata, whose larvae feed on zooplankton, and thereby, indirectly, may affect ciliate dynamics. However, this manipulation did not affect the ciliate community significantly, indicating a decoupling of the top-down effect at a higher trophic level. The weak top-down control on the ciliate community was consistent for 2 consecutive years (see Andrushchyshyn et al. 2003), suggesting that abiotic parameters were more important in governing the ciliate communities than the topdown manipulation tested here, and that the treatment failed to reduce predation pressure on the ciliates. Contrary to what was expected, however, this treatment resulted in a decrease in crustaceans in Pond I and less flagellates and amoebae in Pond II. Although macrofauna are known to predate upon meiofauna (Schmid-Araya \& Schmid 2000), and meiofauna predate upon ciliates (McCormick \& Cairns 1991), unex- 
pected or absent cascading effects from invertebrate predator removal have been reported from several studies. For example, Pace \& Funke (1991) showed that top-down mechanisms were 'truncated' at the level of protists, and Sipura et al. (2003) attributed the absence of community-level cascades to consumer recycling of resources and trophic level heterogeneity. However, Wickham et al. (2004) found that ciliate abundance decreased and the ciliate composition changed when macrozooplankton predators were removed from lake enclosures. Thus, the outcome of food web manipulations is likely habitat specific, partly due to differences in relative abundance of predators and prey, selective feeding, and presence and abundance of alternative prey (review by Sanders \& Wickham 1993), and possibly due to the different mechanisms that prevail in permanent versus intermittent waters.

Since ciliates are an intermediate link between bacteria and zooplankton, high ciliate abundance and strong seasonal community development, as observed in the Vandorf ponds, likely significantly contribute to the seasonal variation in other components of the food web. We conclude that although the Vandorf ciliate populations showed pronounced natural temporal and spatial heterogeneity, together with rapid species succession, responses to some of the manipulations were nonetheless detectable, suggesting that pond physicochemical characteristics and bottom-up trophic effects were important in governing the ciliate community structure in these 2 intermittent ponds.

Acknowledgements. We gratefully acknowledge funding for this project from the Natural Sciences and Engineering Research Council of Canada to D.D.W. We thank K. Wilson and M. Roy for help in the field, A. Tavares for editorial assistance, and 2 anonymous referees for useful comments on the manuscript. We are also very grateful to Dr. and Mrs. P. van Nostrand for permission to work on their property.

\section{LITERATURE CITED}

American Public Health Association, American Water Works Association, and Water Pollution Control Federation (1995) Standard methods for the examination of water and wastewater, 19th edn. Washington, DC

Andrushchyshyn O, Magnusson AK, Williams DD (2003) Ciliate populations in temporary freshwater ponds: seasonal dynamics and influential factors. Freshw Biol 48:548-564

Beaver JR, Crisman TL (1989) Review - the role of ciliated protozoa in pelagic freshwater ecosystems. Microb Ecol 17:111-136

Berninger UG, Wickham SA, Finlay BJ (1993) Trophic coupling within the microbial food web: a study with fine temporal resolution in a eutrophic freshwater ecosystem. Freshw Biol 30:419-432

Bick H (1972) Ciliated protozoa - an illustrated guide to the species used as biological indicators in freshwater biology. World Health Organization, Geneva
Bick H (1973) Population dynamics of protozoa associate with the decay of organic materials in fresh water. Am Zool 13: $149-160$

Chislenko LL (1968) Nomographs for determination of weight of water organisms by sizes and body shape. Academy of Science of USSR, Moscow (in Russian)

Corliss JO (1979) The ciliated protozoa-characterization, classification and guide to the literature. Pergamon Press, Oxford

Curds CR, Gates MA, Roberts DM (1982) British and other freshwater ciliated protozoa. Part I. Ciliophora: Kinetofragminophora. Cambridge University Press, Linnean Society of London, London

Curds CR, Gates MA, Roberts DM (1983) British and other freshwater ciliated protozoa. Part II. Ciliophora: Oligohymenophora and Polyhymenophora. Cambridge University Press, Linnean Society of London, London

Fenchel T (1987) Ecology of Protozoa - the biology of freeliving phagotrophic protists. Springer Verlag, New York

Finlay BJ, Esteban GF (1998a) Freshwater protozoa: biodiversity and ecological function. Biodivers Conserv 7:1163-1186

Finlay BJ, Esteban GF (1998b) Planktonic ciliate species diversity as an integral component of ecosystem function in a freshwater pond. Protist 149:155-165

Finlay BJ, Fenchel T (2004) Cosmopolitan metapopulations of free-living eukaryotes. Protist 155:237-244

Foissner W, Berger H (1996) A user friendly guide to the ciliates (Protozoa, Ciliophora) commonly used by hydrobiologists as bioindicators in rivers, lakes, and waste waters, with notes on their ecology. Freshw Biol 35:375-482

Foissner W, Blatterer H, Berger H, Kohmann F (1991) Taxonomische und ökologische Revision der Ciliaten des Saprobiensystems - Band I: Cyrtophorida, Oligotrichida, Hypotrichia, Colpodea. Informationsberichte Des Bayerischen Landesamtes für Wasserwirtschaft 1:1-478

Foissner W, Berger H, Kohmann F (1992) Taxonomische und ökologische Revision der Ciliaten des Saprobiensystems - Band II: Peritricha, Heterotricha, Odontostomatida. Informationsberichte Des Bayerischen Landesamtes für Wasserwirtschaft 1:1-502

Foissner W, Berger H, Kohmann F (1994) Taxonomische und ökologische Revision der Ciliaten des Saprobiensystems - Band III: Hymenostomata, Prostomatida, Nassulida. Informationsberichte Des Bayerischen Landesamtes für Wasserwirtschaft 1:1-548

Foissner W, Berger H, Blatterer H, Kohmann F (1995) Taxonomische und ökologische Revision der Ciliaten des Saprobiensystems - Band IV: Gymnostomatea, Loxodes, Suctoria. Informationsberichte Des Bayerischen Landesamtes für Wasserwirtschaft 1:1-540

Foissner W, Berger H, Schaumburg J (1999) Identification and ecology of limnetic plankton ciliates. Informationsberichte Heft, Report, Issue 3

Gilbert JJ (1989) The effect of Daphnia interference on a natural rotifer and ciliate community: short-term bottle experiments. Limnol Oceanogr 34:606-617

Gilbert JJ, Jack JD (1993) Rotifers as predators on small ciliates. Hydrobiologia 255:247-253

Goulder R (1971) The effects of saprobic conditions on some ciliated Protozoa in the benthos and hypolimnion of a eutrophic pond. Freshw Biol 1:307-318

Goulder R (1974) The seasonal and spatial distribution of some benthic ciliated protozoa in Esthwaite Water. Freshw Biol 4:127-147

Guhl BE, Finlay BJ, Schink B (1994) Seasonal development of hypolimnetic ciliate communities in a eutrophic pond. FEMS Microbiol Ecol 14:293-306 
Hatano H, Watanabe Y (1981) Seasonal change of protozoa and micrometazoa in a small pond with leaf litter supply. Hydrobiologia 85:161-174

Havens KE, Beaver JR (1997) Consumer vs. resource control of ciliate protozoa in a copepod-dominated subtropical lake. Arch Hydrobiol 140:491-511

Hillebrand H, Kahlert M, Haglund AL, Berninger UG, Nagel S, Wickham S (2002) Control of microbenthic communities by grazing and nutrient supply. Ecology 83:2205-2219

James MR, Burns CW, Forsyth DJ (1995) Pelagic ciliated protozoa in 2 monomictic, southern temperate lakes of contrasting trophic state: seasonal distribution and abundance. J Plankton Res 17:1479-1500

Kahl A (1930) Urtiere oder Protozoa I: Wimpertiere oder Ciliata (Infusoria) 1. Allgemeiner Teil und Prostomata. Tierwelt Deutschlands 18:1-180

Kahl A (1931) Urtiere oder Protozoa I: Wimpertiere oder Ciliata (Infusoria) 2. Holotricha ausser den im 1. Teil behandelten Prostomata. Tierwelt Deutschlands 21: 181-398

Kahl A (1932) Urtiere oder Protozoa I: Wimpertiere oder Ciliata (Infusoria) 3. Spirotricha. Tierwelt Deutschlands 25:399-650

Kahl A (1935) Urtiere oder Protozoa I: Wimpertiere oder Ciliata (Infusoria) 4. Peritricha und Chonotricha. Tierwelt Deutschlands 30:651-886

Kusano H, Kusano T, Watanabe Y (1987) Seasonal succession of a microphagotroph community in a small pond during litter decomposition. Microb Ecol 14:55-66

Madoni P (1991) Seasonal changes of ciliate protozoa in a small pond covered by floating macrophytes. Arch Hydrobiol 121:449-461

Madoni P, Sartore F (2003) Long-term changes in the structure of ciliate communities in a small isolated pond. Ital J Zool 70:313-320

Marchessault P, Mazumder A (1997) Grazer and nutrient impacts on epilimnetic ciliate communities. Limnol Oceanogr 42:893-900

McCormick PV, Cairns J (1991) Effects of micrometazoa on the protistan assemblage of a littoral food web. Freshw Biol 26:111-119

Muylaert K, Van der Gucht K, Vloemans N, De Meester L, Gillis M, Vyverman W (2002) Relationship between bacterial community composition and bottom-up versus topdown variables in 4 eutrophic shallow lakes. Appl Environ Microbiol 68:4740-4750
Müller H, Schöne A, Pinto-Coelho RM, Schweizer A, Weisse $T$ (1991) Seasonal succession of ciliates in Lake Constance. Microb Ecol 21:119-138

Pace ML, Funke E (1991) Regulation of planktonic microbial communities by nutrients and herbivores. Ecology 72: 904-914

Picken LE (1937) The structure of some protozoan communities. J Ecol 25:368-384

Salvado H, Gracia MD (1991) Response of ciliate populations to changing environmental conditions along a freshwater reservoir. Arch Hydrobiol 123:239-255

Sanders R, Wickham S (1993) Planktonic protozoa and metazoa: predation, food quality and population control. Mar Microb Food Webs 7:197-223

Scheiner SH, Gurevitch J (2001) Design and analysis of ecological experiments. Oxford University Press, Oxford

Schmid-Araya JM, Schmid PE (2000) Trophic relationships: integrating meiofauna into a realistic benthic food web. Freshw Biol 44:149-163

Sime-Ngando T, Groliere C (1991) Effets quantitatifs des fixateurs sur la conservation des ciliés planctoniques d'eau douce. Arch Protistenkd 140:109-120

Šimek K, Bobkova J, Macek M, Nedoma J, Psenner R (1995) Ciliate grazing on picoplankton in a eutrophic reservoir during the summer phytoplankton maximum - a study at the species and community-level. Limnol Oceanogr 40: $1077-1090$

Sipura J, Lores E, Snyder RA (2003) Effect of copepods on estuarine microbial plankton in short-term microcosms. Aquat Microb Ecol 33:181-190

Sorokin YI (1999) Aquatic microbial ecology — a textbook for students in environmental sciences. Backhuys Publishers, Leiden

Stoecker DK, Capuzzo JM (1990) Review - predation on protozoa: its importance to zooplankton. J Plankton Res 12: 891-908

Wang CC (1928) Ecological studies of the seasonal distribution of protozoa in a fresh-water pond. J Morph Phys 46: $431-478$

Wickham SA, Nagel S, Hillebrand H (2004) Control of epibenthic ciliate communities by grazers and nutrients. Aquat Microb Ecol 35:153-162

Williams DD (1997) Temporary ponds and their invertebrate communities. Aquat Conserv 7:105-117

Williams DD (2006) The biology of temporary waters. Oxford University Press, Oxford 
Appendix 1. Summary of ciliate occurrence in Ponds I and II (average ciliates per $\mathrm{ml}$ in all enclosures and pondwater control per sampling date, $n=10$ replicates, 17 sampling dates for Pond I and 14 dates for Pond II), with notes on ciliate size $\left(1=10-50 \mu m_{;} 2=50-200 \mu m ; 3>\right.$ $200 \mu \mathrm{m}$ ), habitat preference (p indicates planktonic, all other ciliates are benthic), and sporadic species (s), individual biomass (see 'Materials nad methods: Routine sampling'), feeding preference $(\mathrm{a}=$ algae, $\mathrm{b}=$ bacteria, $\mathrm{c}=$ cyanobacteria, $\mathrm{s}=$ sulphur $\mathrm{bacteria}, \mathrm{d}=\mathrm{diatoms}, \mathrm{h}=\mathrm{hetero-}$ trophic flagellates, $\mathrm{o}=$ omnivorous, $\mathrm{p}=$ predator [mostly ciliates and some small metazoans], $\mathrm{Hi}=$ histophagous), and presence in treatments $(+=$ resource addition, $-=$ resource removal, $\mathrm{p}=$ top-down manipulation, $\mathrm{c}=$ enclosure control, $\mathrm{o}=$ pond-water control). Species identified as important in the first CCA analysis (>10\% fit) are denoted in bold, and the second CCA analysis (>5\% fit) are underlined

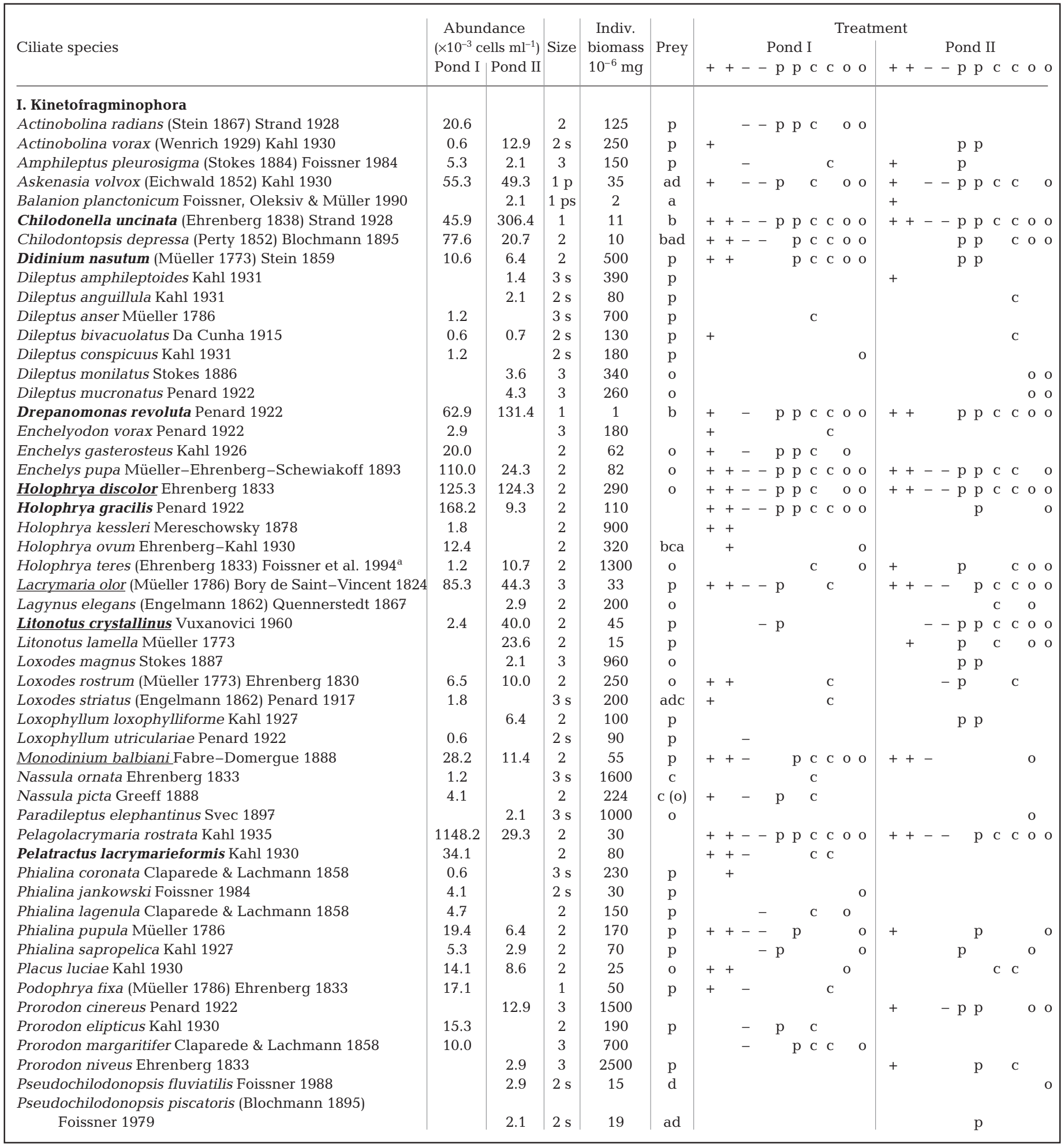


Appendix 1 (continued)

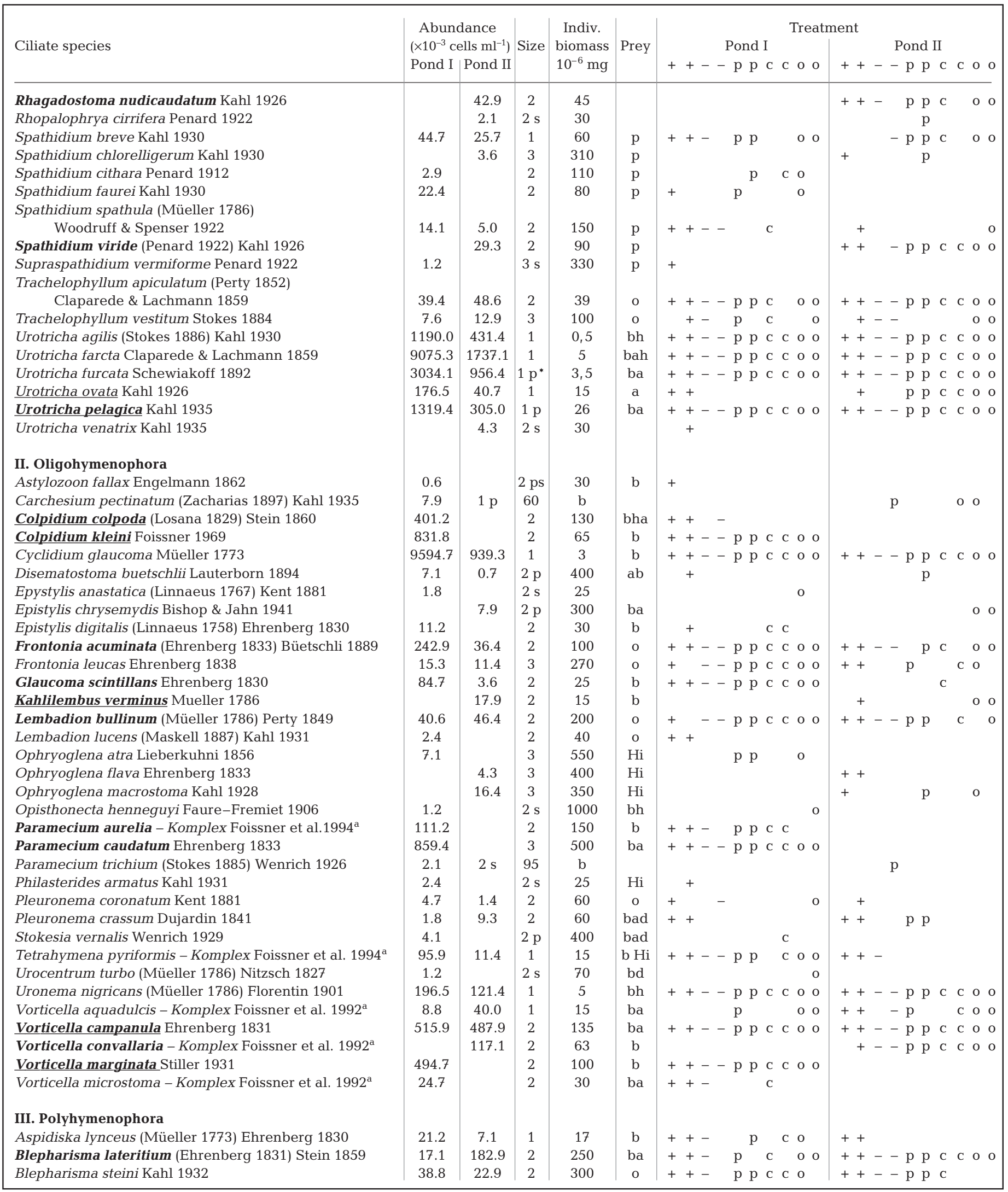


Appendix 1 (continued)

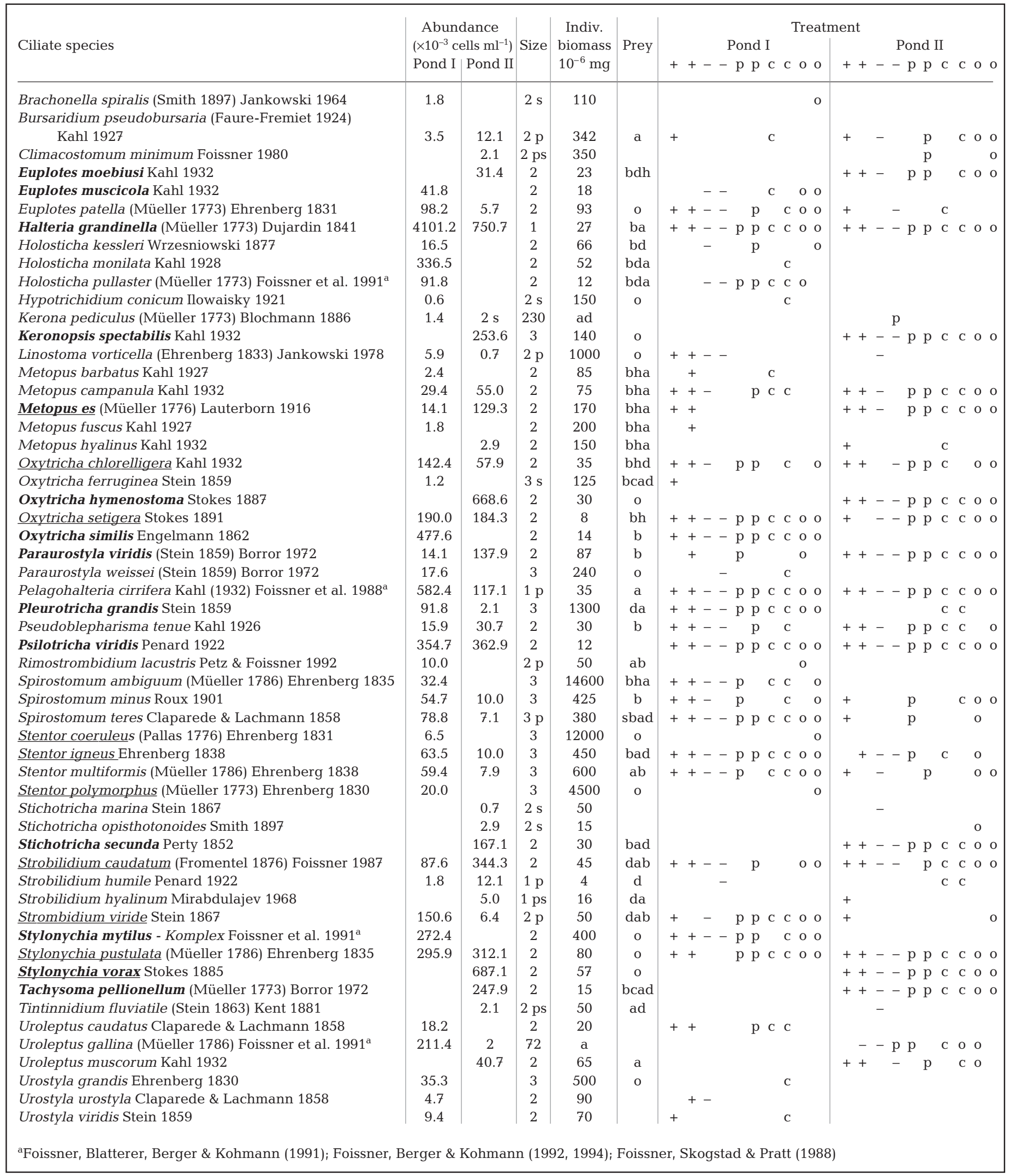

